\title{
WTO's Trade Liberalisation, Agricultural Growth, and Poverty Alleviation in Pakistan
}

\author{
ANWAR F. CHISHTI and WAQAR MALIK
}

\section{INTRODUCTION}

Pakistan is an agrarian based developing country, and like many other developing countries, its agriculture sector is subjected to domestic forces of demand and supply and changes in prices at international level, as well. More specifically, in the late 1990s, the World Trade Organisation (WTO) emerged as one the major players affecting such market changes more vigorously at international arena. The WTO's Agreement on Agriculture, which was established as a result of the 1986-94 Uraguay Round talks, requires, for both developed and developing countries, to initiate a process of reforms in their agrarian economies with the objective of establishing a fair and market oriented agricultural trading system through multilateral trade negotiations. This Agreement on Agriculture (AoA) specifically asks for major reductions in export subsidies, domestic support and import barriers on agricultural products to achieve this objective, the WTO's Agreement of Agriculture [WTO (2001)] had set the following quantitative targets for cuts in each of the three specified area, namely import tariffs, domestic supports and export subsidies.

\begin{tabular}{lcc}
\hline & $\begin{array}{c}\text { Developed } \\
\text { Countries } \\
6 \text { Years } \\
(1995-2000)\end{array}$ & $\begin{array}{c}\text { Developing } \\
\text { Countries } \\
10 \text { Years } \\
(1995-2004)\end{array}$ \\
Period/Time Allowed & $36 \%$ & $24 \%$ \\
\hline Tariff & $15 \%$ & $10 \%$ \\
$\quad$ (1) Average cut for all agricultural products & & \\
$\quad$ (2) Minimum cut per product & $20 \%$ & $13 \%$ \\
Domestic Support & & \\
$\quad$ (1) Total AMS cuts for sector (base period: 1986-88) & $36 \%$ & $24 \%$ \\
$\quad$ Exports & $21 \%$ & $14 \%$ \\
$\quad$ (1) Value of Subsidies & & \\
(2) Subsidised Quantities (base period: 1986-90) &
\end{tabular}

Anwar F. Chishti is Associate Professor at NWFP Agricultural University, Peshawar. Waqar Malik is Member (SS), Pakistan Agriculture Research Council, Islamabad. 
The above reported proposed reductions in import tariffs, domestic supports and export subsidies were to be affected in the developed and developing countries up to years 2000 and 2004, respectively. However, the progress of implementation, reported so far, presents a mixed picture. Gurler (2001) raised some of the concerns of developing countries and reported that, even after the five-year implementation of the WTO Agreements, the developing countries could not observe any improvement in their position. In trade, despite the liberalisation process, areas of export interest to developing countries, particularly agriculture and textile and clothing, remained heavily protected. Capital markets in developing countries were opened up, whereas labour markets in the developed countries were still being protected. Many developing countries felt that, while they had made progress in liberalising their own markets, developed countries were quite slow in this respect. Without consolidating their liberalisation process, the developed countries were rather concerned to expand WTO agreements to include additional and new forms of economic activities such as labour standards, trade investment issues, genetically modified products, electronic commerce, and so on.

While reviewing the implementation in the OECD countries, the FAO (2000) pointed out that, despite reduced AMS levels, total support to agriculture was not declined. Analyses had shown that, not all policies exempt from reduction commitments, were indeed production and trade neutral, as often assumed. To the extent these exempt policies distorted production and trade, the overall positive impact of lower AMS support was undermined.

While commenting on the impact of WTO negotiations on agriculture in Pakistan, Chaudhry (2001) opined that the reform programme under WTO could help Pakistan to raise agricultural production substantially provided Pakistan ensure world level commodity prices, replace government intervention with regulated private marketing system, improve efficiency of input delivery systems, invest in market infrastructure for exports and undertake steps to ensure quality exports. He further argued that Pakistan had considerable potential in export of leather and leather madeups, spices, flowers plants and tropical nuts and fruits where developed countries had promised to reduce tariffs. However, being a net importer of staple foods, Pakistan would face rising food import prices as a result of reduction in agricultural support and export subsidies. The benefits to Pakistan "would accrue only if (a) agreements are fully implemented by all the countries in letter and spirit; (b) sanitary and phytosanitary measures, anti-dumping and labour laws, environmental protection and quality standards are not misused to restrict trade; and (c) benefits from technological breakthroughs are not restricted to the developed world".

Niaz (2001) and Salam (2001) elaborated on Pakistan's support price policy and mentioned that AMS in case of Pakistan was negative and was thus within the de-minimise limits. Niaz (2001) further reported that the analysis of import/export 
parity prices for important agricultural commodities for the last 3-5 years had been considerably below their corresponding border prices. So, WTO was not going to be a factor to be reckoned with for not continuing with support price policy at least for some years to come. However, he argued that, in view of the recent development in economic policy and WTO commitments, there was "a need to develop further indigenous competence, expertise and institutional capacity to address the emerging policy issues. The policy-makers must have before them well analysed facts and figures giving different options for decision making”.

The WTO, in its recent 4th Ministerial Conference held in Doha in November 2001, reaffirmed "the principles and objectives set out in the Marrakesh Agreement Establishing the World Trade Organisation" and pledged "to reject the use of protectionism". The Conference reconfirmed its commitment to the programmes embodied in the AoA and committed itself "to comprehensive negotiations aimed at: substantial improvements in market access; reductions of, with a view to phasing out, all forms of export subsidies; and substantial reductions in trade-distorting domestic support”. The Conference also took note of various concerns of developing countries and chalked out work programmes for various interest areas, with the commitment that negotiations would be pursued and completed before January 2005 [WTO (2001a)].

Being a signatory of the WTO, the Government of Pakistan (GoP) would have to adopt the measures asked for to liberalise agricultural sector. The emerging situation necessitates a detailed and comprehensive research study, which covers all major important related aspects of the opening of economies and trade liberalisation phenomenon emerging all over the world. This particular paper presents a theory-based graphical analysis, which may be further used for a complete empirical study of the pros and cons of WTO's trade liberalisation for Pakistan economy with specific emphasis on sustained growth of agricultural sector and poverty alleviation in Pakistan.

\section{TRADE LIBERALISATION: A THEORETICAL FRAMEWORK FOR CAPTURING EFFECTS}

It is a well-known general tendency of the human nature that he/she responds to price changes differently when he is a supplier or producer of a commodity versus the situation when he acts as a consumer or buyer of the same commodity. When price increases, a producer enhances his production or supply (panel a of Figure 1), but at the same time, a buyer reduces his consumption or demand for that commodity (panel b).

This general tendency of human nature (generally referred to as the principles or laws of supply and demand in the discipline of economics) provides the basis of a compromise on an agreed price and quantity supplied and demanded (panel c).

The general Marshalian paradigm, presented in panel (c) of Figure 1, whereas, represents how the forces of supply and demand determine prices in the market, it 
also indicates that, while behaving differently to price changes, the producers and consumers, in fact, try to maximise their respective social surpluses (PS and CS). Producer tries to maximise producer surplus (PS) - the area above the supply curve and below the price line — and consumer tries to maximise consumer surplus (CS) the area below the demand curve and above the price line (panel c of Figure 1). Whereas the PS represents the 'profits' to the producer, CS represents the 'savings' to the consumers.

(a)

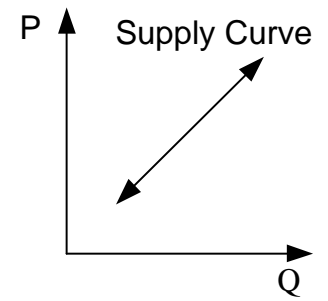

(b)

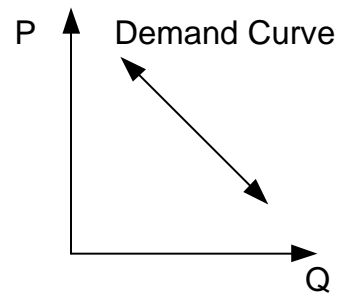

(c)

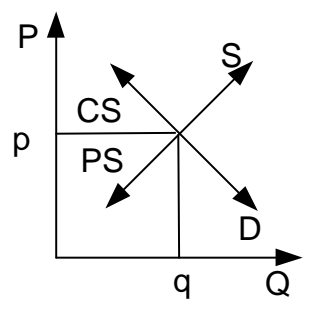

Fig. 1. Supply-demand, Prices and Social Surpluses.

The position of the price line and curvatures/slopes of the supply and demand curves determine the volumes/magnitudes of the producer and consumer surpluses. Panel (c) of Figure 1 suggests that any change in the position of price or any rightward or leftward shift of the supply and/or demand curve will change the magnitudes of the PS and CS. It should also be noted that any positive change in PS would mean a reciprocal negative change in CS and vice versa. This phenomenon thus provides a mechanism to compare and evaluate an intervention or policy on the basis of changes in the PS and CS; a better policy would thus be the one, which yields net social gains (NSG) to the society, instead of incurring net social cost (NSC) defined, as follows.

$$
\begin{array}{llllll}
\mathrm{NSG}=\Delta \mathrm{PS}+\Delta \mathrm{CS}>0 & \ldots & \ldots & \ldots & \ldots & \ldots \\
\mathrm{NSC}=\Delta \mathrm{PS}+\Delta \mathrm{CS}<0 & \ldots & \ldots & \ldots & \ldots & \ldots
\end{array}
$$

Some of the interventions/policies are accompanied with some other gains like import and export tax collections and some are accompanied with subsidies and other costs; all such gains and losses should also be added/accounted for in the above equations for a fair evaluation of the policy under study. ${ }^{1}$

${ }^{1}$ For a review of the concepts of social surpluses (PS, CS) and their uses as a criterion for comparing effects of various policies and interventions, see Chishti (1994, pp. 32-47). 


\section{WTO'S TRADE LIBERALISATION: THEORY-BASED GRAPHICAL ANALYSIS ${ }^{2}$}

Of the several implications of WTO's trade liberalisation, we take the following four specific cases for detailed analysis.

(a) Opening of the closed economy.

(b) Reduction/elimination of Aggregate Measures of Support (AMS).

(c) Reduction of tariffs on imports.

(d) Reduction/elimination of export subsidies.

\subsection{Autarky-to-Open Economy}

Though, the Government of Pakistan (GoP) has substantially reduced the number of products included in its negative lists (banned for import or prohibited for export), there are still a number of products banned for import in or export from Pakistan. In case the numbers of such products are further reduced or the negative lists are altogether eliminated, the effect on domestic economy would be, as follows.

\section{(a) A Case When World Price (Pw) > Domestic Price (Pd)}

If the world price $\mathrm{Pw}$ of the commodity involved is higher than the domestic price Pd, the opening of economy would help introduce the world price Pw prevailed in the domestic market, which would induce the domestic producers to increase their production from the closed economy level of 'ab' to the new level of 'cd'. (Panel a of Figure 2). The domestic consumer, on contrary, would reduce their consumption from

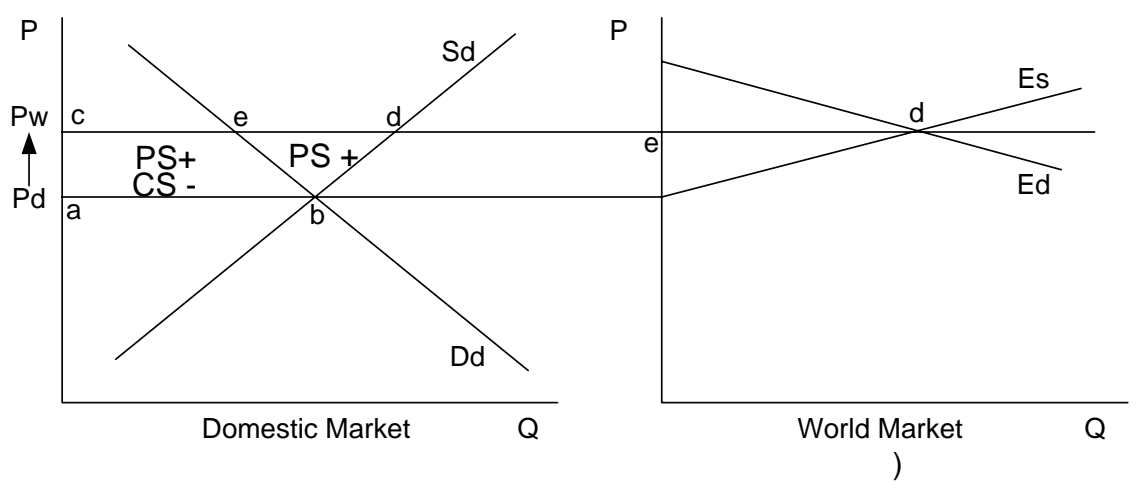

Fig. 2(a). Autarky is Relaxed (When Pw $>$ Pd).

${ }^{2}$ For more details on the following and similar analysis, see Houck (1986); Gardner (1988, 1988a); Knutson, Penn and Boehm (1990); Tweeten (1992) and Chishti (1991, 1994, 1997). 
'ab' level to 'ce' level, leaving an exportable surplus equal to 'ed', which would be exported to the world market on a price Pw. Consequently, producer surplus (PS) would be up by an area equal to 'abdc', consumer surplus (CS) would be lower by 'abec'; and end-result would be a net social gain (NSG) equal to area 'bde'. Summarising the results,

If $\mathrm{Pw}>\mathrm{Pd}$, then

$$
\begin{array}{llrrrrr}
\Delta \mathrm{PS}=(\text { abdc })>0 & \ldots & \ldots & \ldots & \ldots & \ldots & \ldots \\
\Delta \mathrm{CS}=(\text { abec })<0 & \ldots & \ldots & \ldots & \ldots & \ldots & \ldots \\
\mathrm{NSG}=\Delta \mathrm{PS}+\Delta \mathrm{CS}=(\text { bde })>0 & \ldots & \ldots & \ldots & \ldots
\end{array}
$$

\section{(b) A Case When World Price (Pw) < Domestic Price (Pd)}

If the world price Pw is lower than domestic price Pd, Pakistan would become a net importer, as reflects in Panel b of Figure 2.

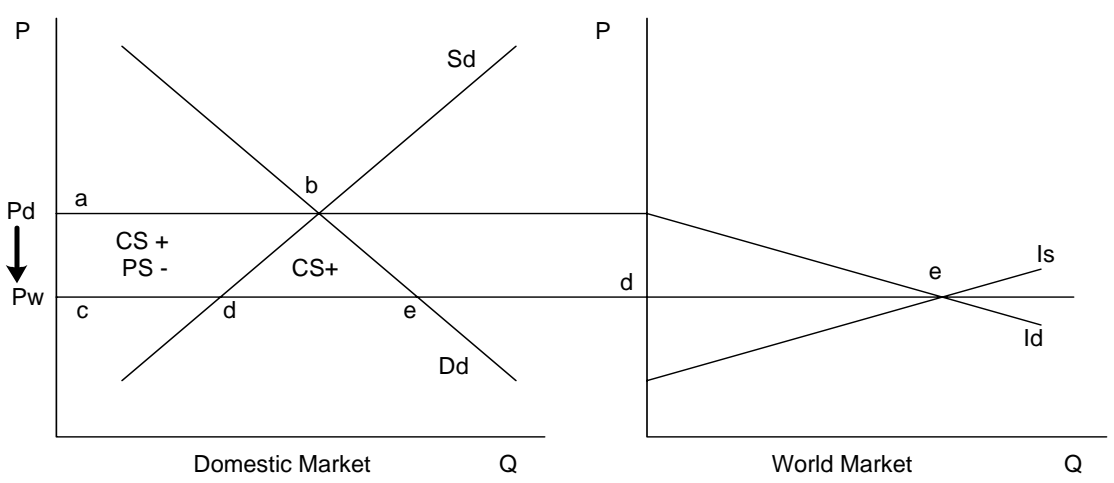

Fig. 2(b). Autarky is Relaxed (When $P w<P d)$.

The lower Pw would depress domestic production from the existing level of ' $a b$ ' to 'cd'; the lower Pw would encourage domestic consumption from existing 'ab' to 'ce', resulting in a net demand for import equal to 'de'. As a consequence of the lower world price, the PS would decrease, CS would increase and, again, there would be a NSG equal to area 'deb', as indicated below.

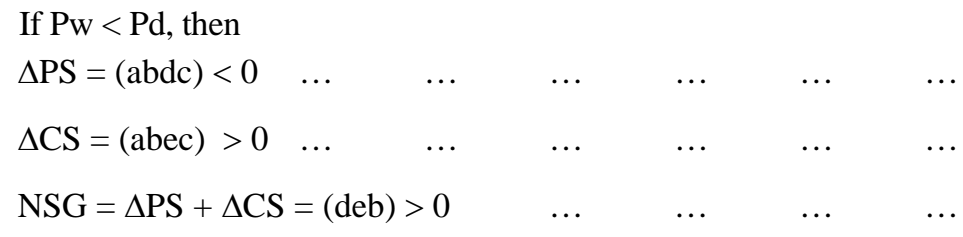


It should be noted that if autarky is relaxed and economy is opened to outside competition, whether a country becomes an exporter or importer, it reaps net social gains; however, the producers gain and consumers hurt in the former case, and consumers gain and producers hurt in the latter case.

\subsection{Reduction/Elimination of Aggregate Measures of Support (AMS)}

The WTO trade liberalisation requires that the Aggregate Measures of Support (AMS), which include both subsidies and price supports provided to producers in domestic market, be reduced, and eliminated ultimately. Pakistan has already abandoned its input subsidising programme; however, its price support programme still continues for some major agricultural commodities. Figure 3 (a \& b) represents the cases of reduction or elimination of price supports for an exporting and importing country, respectively.

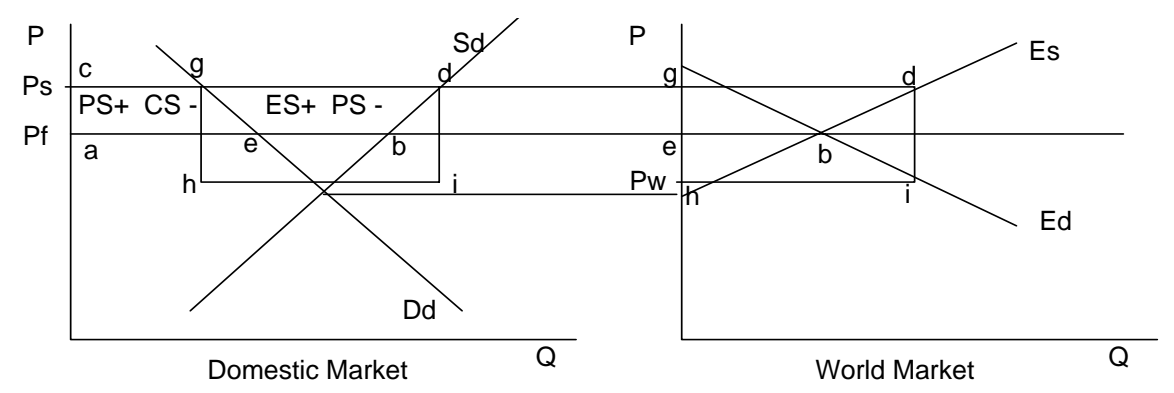

Fig. 3(a). Price Support Relaxed (Exporter Case).

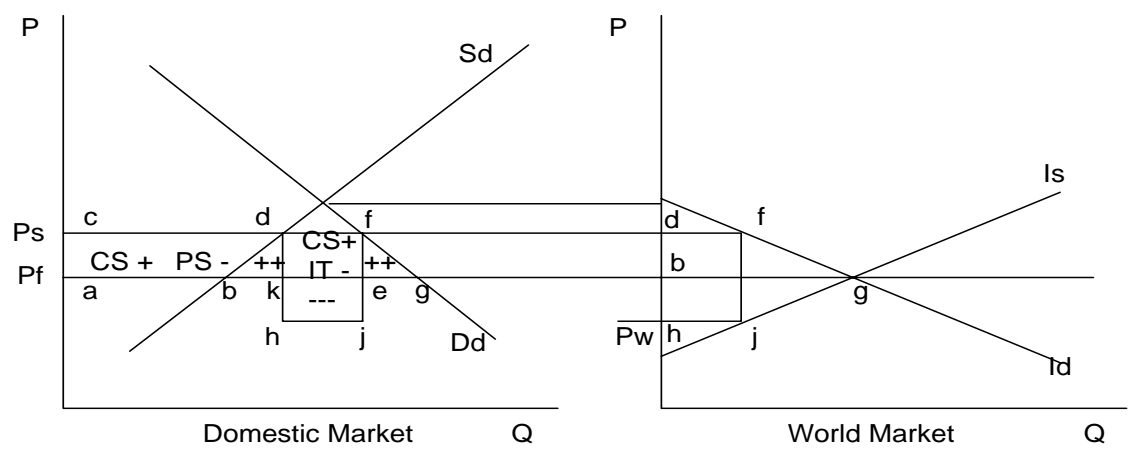

Fig. 3(b). Support Price is Relaxed (Importer Case). 


\section{(a) Relaxing Price Support (An Exporter Case)}

If the country is already exporting a commodity and the government decides to support its price above the free market price Pf, the price supported at Ps would enhance domestic production from 'ab' to 'cd' level and exportable surplus from 'eb' to 'gd' level.. The enhanced exportable surplus 'gd' would depress the world price and the government would have to dispose off its exportable surplus at a world price Pw, which is lower than its domestic support price Ps. The government would thus have to provide a subsidy on export - equal to the difference between Ps and Pw-to maintain Ps at its supported level; otherwise, the exportable surplus would not be disposed off in international market and the price support mechanism would collapse due to availability of heavy stocks in domestic market. In case the support price is reduced/eliminated, the Ps decreases to Pf, domestic production declines from ' $c d$ ' to 'ab' level, domestic consumption increases from 'cg' to 'ae' and exportable surplus reduces from 'gd' to 'eb' free market level. Since exportable surplus 'eb' is easily disposed off at free market price Pf, there would be no need to grant export subsidy (ES = 'hidg'); the cost of subsiding export would thus be saved. The changes in social surpluses would be, as follows.

If Ps $\rightarrow$ Pf (in an exporting country), then

$$
\begin{array}{rlrrrrr}
\Delta \mathrm{PS}=(\text { abdc })<0 & \ldots & \ldots & \ldots & \ldots & \ldots & \ldots \\
\Delta \mathrm{CS}=(\text { aegc })>0 & \ldots & \ldots & \ldots & \ldots & \ldots & \ldots \\
\Delta \mathrm{ES}=(\text { hidg })>0 & \ldots & \ldots & \ldots & \ldots & \ldots & \ldots \\
\text { NSG }=\Delta \mathrm{PS}+\Delta \mathrm{CS}+\Delta \mathrm{ES}=(\text { eghidb })>0 & \ldots & \ldots & \ldots
\end{array}
$$

\section{(b) Relaxing Price Supports (An Importer Case)}

If the country is already an importer of the commodity (Figure 3, panel b) and the government decides to support its price above the free market price Pf, the price supported at Ps would cause domestic production to increase from 'ab' to 'cd' level, domestic consumption to decrease from 'ag' to ' $\mathrm{cf}$ ' and import quantity to decline from 'bg' to 'df' level. The depressed demand for import 'df' decreases the world price and the country imports the commodity 'hj' on a lower world price Pw, sells it on a higher domestic price Ps and, in the process, receives import tax equal to the difference between the two price levels to maintain Ps at its supported level; otherwise, the price support mechanism collapses due to the availability of stocks on lower price in international market. In case the support price is reduced/eliminated, the Ps decreases to Pf, domestic production declines from 'cd' to 'ab', domestic consumption increases from ' $\mathrm{cf}$ ' to 'ag' and import demand increases from ' $\mathrm{df}$ ' to 
'bg' level. Since import demand 'bg' is easily met at free market price Pf, there would be no import tax (IT) received by the government.

The changes in social surpluses would be, as follows.

If Ps $\rightarrow$ Pf (in an importing country), then

$$
\begin{array}{ccccccc}
\Delta \mathrm{PS}=(\text { abdc })<0 & \ldots & \ldots & \ldots & \ldots & \ldots & \ldots \\
\Delta \mathrm{CS}=(\text { agfc })>0 & \ldots & \ldots & \ldots & \ldots & \ldots & \ldots \\
\Delta \mathrm{IT}=(\text { hjfd })<0 & \ldots & \ldots & \ldots & \ldots & \ldots & \ldots \\
\mathrm{NSG} / \mathrm{C}=\Delta \mathrm{PS}+\Delta \mathrm{CS}+\Delta \mathrm{IT}=\{\text { (bkd) }+(\text { egf })\}-(\text { hjek }) \geq 0 \text { or } \leq 0 & \ldots
\end{array}
$$

Equation 16 indicates that whether there would be net social gain or cost (NSG/C) of reducing/elimination of price support is not clear as it would depend on differences in magnitude of the area $\{(\mathrm{bkd})+($ egf $)\}$ indicating savings in CS and area (hjek) representing net losses in IT.

\subsection{Reduction of Tariffs on Imports}

As Figure 4 reflects, when a tariff is imposed on an import, the import demand curve shifts inward from If position to It position. The It curve intersects export supply curve Es at a point which sets world price at $\mathrm{Pw}$ and domestic price at Pt against the earlier common Tariff-free market price Pf; consequently, an import tax (IT)—equal to area 'edhg'-is collected on account of tariff or import duties imposed.

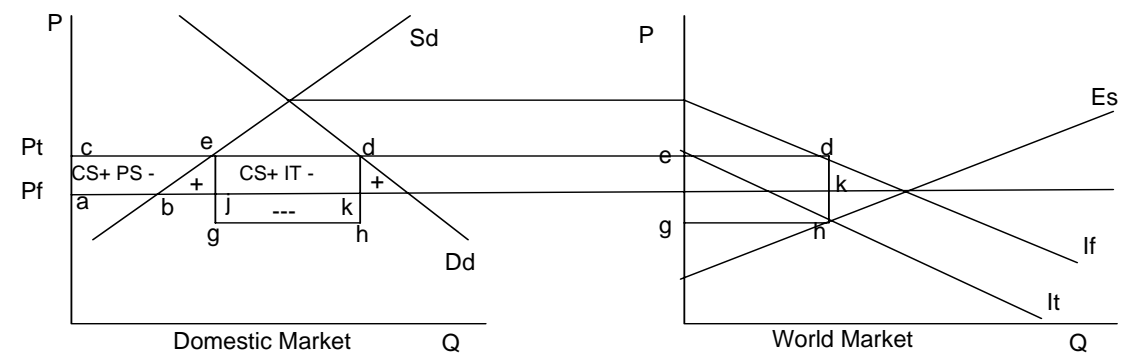

Fig. 4. Import Tariff Relaxed.

The elimination of tariff on import would mean reduction in PS by area 'abec', increase in CS by area 'akdc' and elimination of IT altogether. The changes would thus be:

If tariff $\rightarrow 0$ and Pt $\rightarrow$ Pf, then

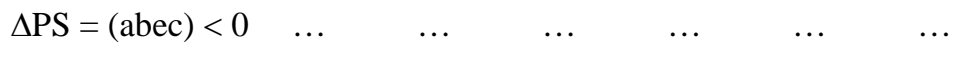




$$
\begin{aligned}
& \Delta \mathrm{CS}=\left(\begin{array}{lllllll}
\text { akdc })>0 & \ldots & \ldots & \ldots & \ldots & \ldots & \ldots
\end{array}\right.
\end{aligned}
$$

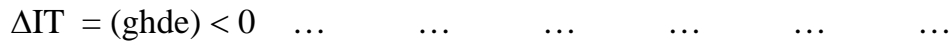

$$
\begin{aligned}
& \mathrm{NSG} / \mathrm{C}=\Delta \mathrm{PS}+\Delta \mathrm{CS}+\Delta \mathrm{IT}=\{(\text { bie })+(\mathrm{jkd})\}-(\text { ghji }) \geq 0 \text { or } \leq 0 \quad \ldots
\end{aligned}
$$

Equation 20 indicates that, whether there would be net social gain or cost (NSG/C) of reducing/elimination of tariff, it is not clear as it would depend on differences in magnitudes of the areas $\{(\mathrm{bie})+(\mathrm{jkd})\}$ indicating savings in CS and area (ghji) representing net losses in IT.

\subsection{Reduction/Elimination of Export Subsidies}

These are mainly the USA and EC, which heavily subsidise their exports. Pakistan, itself, does not provide export subsidies. The elimination of subsidies on exports in international market would result in higher prices of these exports. This would affect Pakistan in two ways: (a) as an exporter of the commodity; (b) as an importer of the commodity.

\section{(a) Effect on Pakistan as an Exporter}

The Es and Is curves, in Panel (a) of Figure 5, represent, respectively, the export supply and import demand curve of Pakistan exports in an international market, where the US and EC exercise export subsidies. The resultant price for Pakistani export is Ps. If the US and EC reduce or abolish its subsidies, their export prices would go up, giving a chance for Pakistani products to be substituted for highpriced US/EC exports. The demand for Pakistani exports would thus enhance and the Is curve would shift to a new position at If, resulting in a higher export price for Pakistani commodities at Pf.

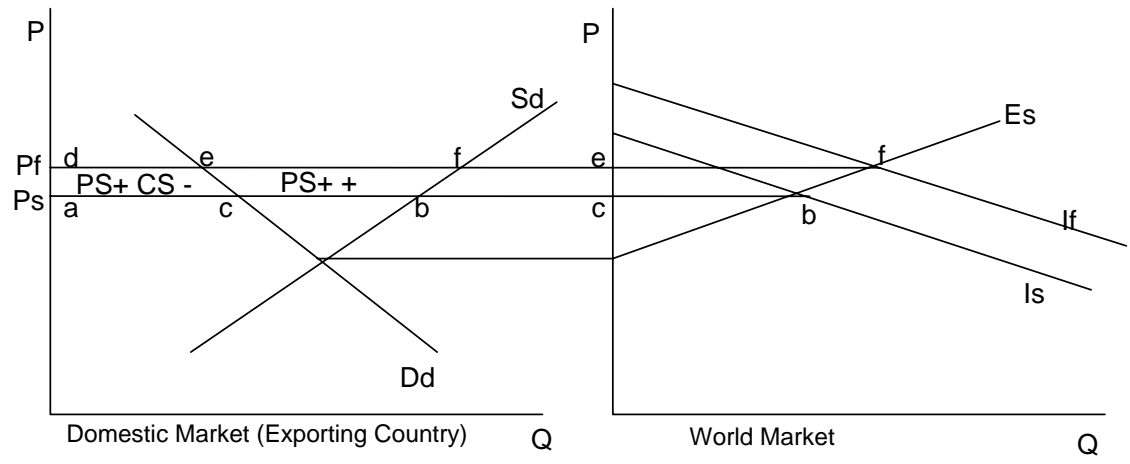

Fig. 5(a). Foreign Export-subsidies Withdrawn (An Exporter Case). 
The reduction or elimination of foreign export subsidies would thus help Pakistan to have a higher demand for its exports and higher prices. As a result, the PS would increase by an area equal to 'abfd', CS would decrease by 'aced', and there would be a NSG equal to area 'cbfe'.

If foreign export subsidies $\rightarrow 0$ and Ps $\rightarrow$ Pf, then

$$
\begin{array}{lllllll}
\Delta \mathrm{PS}=(\text { abfd })>0 & \ldots & \ldots & \ldots & \ldots & \ldots & \ldots \\
\Delta \mathrm{CS}=(\text { aced })<0 & \ldots & \ldots & \ldots & \ldots & \ldots & \ldots \\
\mathrm{NSG} & =\Delta \mathrm{PS}+\Delta \mathrm{CS}=(\text { cbfe })>0 & \ldots & \ldots & \ldots & \ldots
\end{array}
$$

\section{(b) Effect on Pakistan as an Importer}

The Es and Id curves, in Panel (b) of Figure 5, represent, respectively, the export supply and import demand curve of Pakistan imports in an international market, where the US and EC provide export subsidies. The resultant price for Pakistani imports is Ps. If the US and EC reduce or abolish its export subsidies, their export supply curve would shift inward from Es to Ef position. The newly shifted export supply curve would intersect Pakistan's import demand curve Id at Pf, a point which is higher than the export-subsidy-regime price of Ps. Consequently, PS would increase by an area equal to 'abed', CS would decrease by area 'acfd', and there would be a NSC equal to area 'bcfe'.

If foreign export subsidies $\rightarrow 0$ and Ps $\rightarrow$ Pf, then

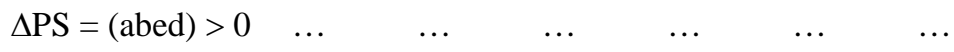

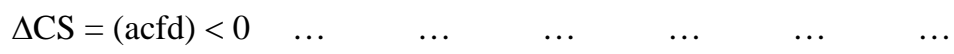

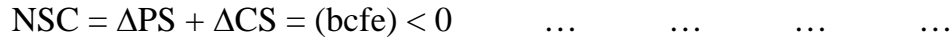

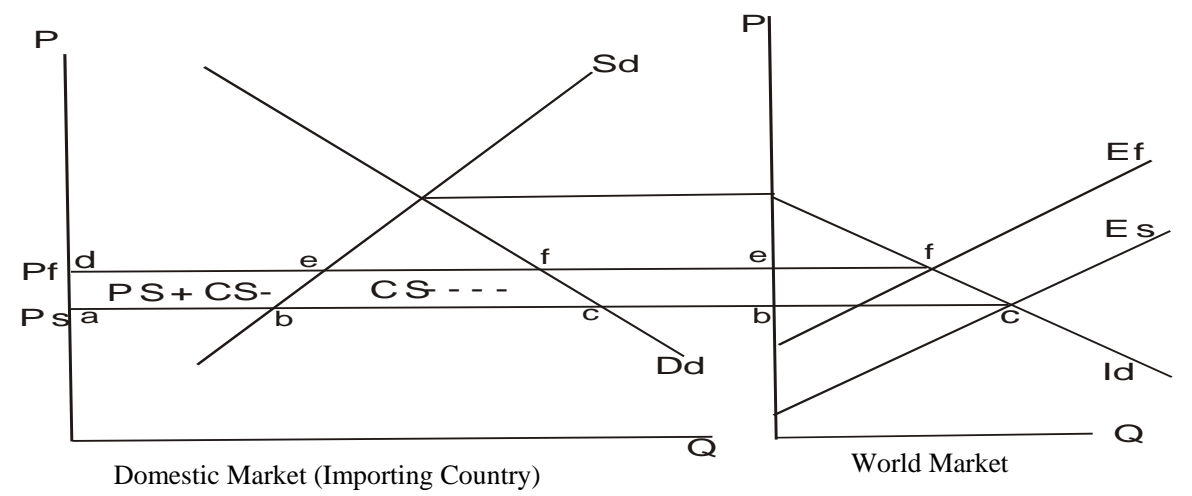

Fig. 5(b). Foreign Exports-subsidies Withdrawn (An Importer Case). 


\section{RESULTS: DISCUSSION AND IMPLICATIONS}

\section{Summary of Results}

The results of the theoretical analysis carried out in the previous section are reproduced in a summarised form, as follow.

\begin{tabular}{|c|c|c|c|c|c|}
\hline \multirow[b]{2}{*}{ Liberalisation Moves } & \multirow[b]{2}{*}{$\Delta \mathrm{PS}$} & \multirow[b]{2}{*}{$\Delta \mathrm{CS}$} & \multicolumn{2}{|c|}{$\begin{array}{c}\text { Saving/Dis- } \\
\text { saving to } \\
\text { Treasury } \\
\end{array}$} & \multirow{2}{*}{$\begin{array}{l}\mathrm{NSG}>0 \\
\mathrm{NSC}<0\end{array}$} \\
\hline & & & $\overline{\Delta \mathrm{ES}}$ & $\Delta \mathrm{IT}$ & \\
\hline \multicolumn{6}{|c|}{ (a) Opening of Closed Economy } \\
\hline (1) If $\mathrm{Pw}>\mathrm{Pd}$ & $>0$ & $0<$ & - & - & $>0$ \\
\hline (2) If $\mathrm{Pw}<\mathrm{Pd}$ & $<0$ & $>0$ & - & - & $>0$ \\
\hline \multicolumn{6}{|l|}{ (b) Relaxing Price Supports } \\
\hline (1) As an Exporter & $<0$ & $>0$ & $>0$ & - & $>0$ \\
\hline (2) As an Importer & $<0$ & $>0$ & - & $<0$ & $?$ \\
\hline \multicolumn{6}{|l|}{ (c) Relaxing Tariffs on } \\
\hline Imports & $<0$ & $>0$ & - & $<0$ & ? \\
\hline \multicolumn{6}{|c|}{ (d) Export Subsidies Withdrawn } \\
\hline (1) Pak as an Exporter & $>0$ & $0<$ & - & - & $>0$ \\
\hline (2) Pak as an Importer & $>0$ & $0<$ & - & - & $0<$ \\
\hline
\end{tabular}

\section{Relaxing Autarky/Opening of Closed Economy}

If autarky is relaxed, Pakistan may become an exporter or importer. It would become an exporter of the commodities for which the world prices are higher than Pakistan's existing domestic prices. The higher world prices would prevail in the domestic economy, which would help producers to engage more resources for higher outputs. The income of producers of such commodities, resource suppliers and traders engaged in domestic and export trade would increase. This would positively contribute to poverty reduction. However, consumers would lose in the process; the domestic consumption and consumers' surplus would decline. This would partially offset the producers' gains, but, society, as a whole, would gain as the positive producer surpluses would exceed losses to the consumers.

In contrast, Pakistan would become an importer for the commodities for which world prices are lower than Pakistan's domestic prices. The opening of 
economy would help prevail world prices in domestic market. The lowered domestic prices would depress domestic production and incur losses in producer surpluses. The lowering of domestic output would help relieve resources for some more efficient uses. The losses in producer surpluses would also be offset by higher gains in consumer surpluses due to the savings to consumers caused by lowered prices. Efficient re-allocation of resources and higher savings to consumers (relative to lower losses in producer surpluses) would help alleviate poverty in the society.

\section{Relaxing Price Supports}

Whenever price is supported in an already exporting country, the domestic output would increase, but domestic consumption would decline due to higher supported price. There would thus be higher exportable stocks available, and the country concerned would therefore have to rely on export subsidies to dispose off the so achieved additional exportable stocks. Hence, whenever, support price is relaxed in such a situation, it would reduce domestic output, increase domestic consumption, and there would also be less exportable surplus available. There would be no export subsidies required to dispose off this exportable surplus. These savings in export subsidies, coupled with increases in consumer surpluses (due to lowered domestic prices) would be higher than the losses in producer surpluses; there would be thus net social gains.

In contrast, in an already importing country, an import tax has to be imposed to maintain a support price, and when such a support price is relaxed, the import tax is vanished. Hence, when support price is relaxed, it is the gains in consumer surpluses (caused by lowered prices) that are compared with the losses in producer surpluses coupled with import-tax-revenues foregone. The graphical analysis carried out (Figure 3-b) does not provide full insight for such a comparison; an empirical estimation based on the model presented in Equations 13 to 16 would help.

\section{Relaxing Import Tariffs}

When an import tariff is relaxed, the domestic price for the imported good is lowered, which, in turn, would depress domestic output and producer surpluses. The lowered output would help release some of the resources to be more efficiently used in some other sectors. The losses in producer surpluses would be completely balanced out by gains in consumer surpluses caused by lowered domestic prices. Gains in consumer surpluses would exceed the losses in producer surpluses, and there would some surplus gains (ebkd) left to meet the losses in import duties or tariff collections (eghd; Fig. 4). The graphical analysis carried out does not indicate whether the savings to consumers, in the form of consumer surpluses, would fully compensate the losses in tariff collection; empirical estimation suggested in Equation 20 would help solve the problem. 


\section{Reduction/Elimination of Foreign Export Subsidies}

Withdrawal of subsidies on exports by foreign exporters would increase the prices of their exports, which, would, in turn, encourage Pakistani exports to substitute for the high priced foreign exports. Higher demand for Pakistani exports would result into higher output, higher absorption of resources and higher producer surpluses. Higher product prices would also be accompanied with some losses to the consumers in the form of lower consumer surpluses. However, gains to producers would be much higher than the losses to the consumers, and therefore society, as a whole, would gain.

Withdrawal of export subsidies by foreign suppliers would also mean higher prices for Pakistani imports. Consequently, domestic output of such imported products would enhance, which would employ some more resources. Producers would gain, but gains in producer surpluses would not be enough to compensate the total losses to consumers in their consumer surpluses caused by higher domestic prices.

\section{CONCLUSION}

The theory based graphical analysis carried out in the preceding section leads to some very important conclusions, namely:

First, the opening-of-close-economy move would help Pakistan to become an exporter of the commodities we have some comparative advantage, and an importer for the products the others have comparative advantage. In the former case, the enhanced domestic output, triggered by greater demand for exports would bring extra resources absorbed in such commodity sectors. The enhanced gains in producer surpluses would be greater than the losses in consumer surpluses, and economy, as a whole, would gain. In the latter case, the opening of economy would encourage some imports and discourage domestic production, resulting in lower producer surpluses and relieving some resources for efficient uses elsewhere. The gains in consumer surpluses would, however, be greater than the losses in producer surpluses, and the economy would gain.

Second, though the abolition of price support policy would produce gains for the exportable commodities for the society as a whole, it would incur some losses to the producers. Such losses to domestic producers may reverse due to enhanced demand of Pakistani exports triggered by export subsidy withdrawal by foreign exporters. This implies that efforts should be made to persuade the US and EC,- - the world major export-subsidy providers - to abolish export subsidies. The enforcement of export subsidy withdrawal by foreign exporters would also help reduce losses in producer surpluses caused by enhanced imports due to support price abolition and import-tariff relaxation. 
Third, reduction of import-tariffs would encourage imports due to lowered import prices. Withdrawal of subsidies on exports by foreign exporters would balance out some of the losses in producer surpluses caused by the cuts in tariffs and resultant higher imports. Cuts in tariffs would also lessen the domestic cost of production, inflation and smuggling in.

Fourth, of the WTO's liberalisation policies, opening of closed economy for exportables, and withdrawal of export subsidies by foreign exporters would be proproducers; these policies would help absorb new resources and enhance producer surpluses, and would therefore directly contribute to poverty alleviation. Opening of economy for importables, withdrawal of price supports and tariff-cuts on imports would reduce domestic outputs, but at the same time, would relieve resources for their more efficient uses elsewhere. In addition, these policies would yield savings to consumers and would positively contribute towards poverty reduction. Cuts in tariffs on imports would cause declines in government revenues, but these cuts are also expected to control smuggling and enhance greater imports through legal routes, resulting in higher import tax revenues to government treasury. Policies aiming at greater imports would need higher volumes of foreign exchange, which are expected to be sufficiently generated by higher exports in the new competitive system.

Last, these trade liberalisation moves would help minimise control of individuals on trade. This would leave less room for an individual policy-makers or tax collectors to use their discretionary powers and exploit the situations in their own or someone else interest. This would help lessened the role and importance of various pressure groups and their chances of exploitation, and would lead the economy to be run in accordance with the forces of supply and demand based on the last lasting general tendency of human nature. This is how we can achieve a sustainable and stable growth in agriculture and other sectors of our economy. But Pakistan, in isolation, would not be able to achieve a durable sustained growth; a more durable sustainability would be achieved when the liberalisation is pursued and enforced world over.

\section{REFERENCES}

Chaudhry, M. Ghaffar (2001) Impact of WTO Negotiations on Agriculture in Pakistan and Implication for Policy. Pakistan Journal of Agricultural Economics 4:1.

Chishti, A. F. (1991) Economic Implications of Taxing Agricultural Exports: A Case Study of Pakistan Basmati Rice. Paper presented in XXI Conference of International Association of Agricultural Economists, 20-29 August, Tokyo.

Chishti, A. F. (1994) An Evaluation of Pakistan's Rice Trade Policy: A Case Study of Basmati Rice. PhD Dissertation, University of Illinois, Urbana-Champaign, USA. 
Chishti, A. F. (1997) Analysing Productivity Gains in the Presence of Restricted Exports Regime. Journal of Rural Development and Administration 29:2.

Food and Agriculture Organisation (2000) Experience with the Implementation of the Uruguay Round Agreement on Agriculture. Committee on Commodity Problems, Document: CCP:01/11, p. 3.

Gardner, Bruce (1988) A Framework for Analysing Commodity Programmes. Department of Agriculture and Resource Economics. University of Maryland. (Working Paper No. 88-5.)

Gardner, Bruce (1988a) The Economics of Agricultural Policies. New York: Macmillan Publishing Company.

Gurler, Oker (2001) Monitoring Report on the Activities of the WTO: Positions of the Developing Countries. In Journal of Economic Cooperation Among Islamic Countries 22:2, 31-60.

Houck, James P. (1986) Elements of Agricultural Trade Policies. New York: Macmillan Publishing Company.

Knutson, Ronald D., J. B. Penn, and William T. Boehm (1990) Agricultural and Food Policy. 2nd ed. New Jersey: Prentice Hall, Englewood Cliffs.

Niaz, M. Shafi (2001) Deregularisation of Agricultural Prices. Opening Address Delivered at the National Seminar held at University of Agriculture, Faisalabad on 20 October.

Pakistan, Government of (2001) Economic Survey 2000-2001. Islamabad: Economic Advisor's Wing. Finance Division.

Salam, Abdul (2001) Deregulation of Agricultural Prices, Key Note address delivered at the National Seminar held at University of Agriculture, Faisalabad on 20 October.

Tweeten, Luther (1992) Agricultural Trade: Principles and Policies. London: Westview Press/IT Publications.

WTO (2001) The Uruguay Round Final Act: Full texts, Agreement on Agriculture. WTO's website: www.wto.org

WTO (2001a) Ministerial Declaration, Ministerial Conference, Fourth Session, Doha, 9-14 November. WTO's website: www.wto.org

Zaidi, S. Akbar (1999) Issues in Pakistan's Economy. Karachi: Oxford University Press. 


\section{Comments}

Let me begin by congratulating the authors on producing an excellent theoretical paper to draw the attention of policy-makers to free trade theory. The paper is a timely exercise as the government is currently preoccupied in preparing a policy consistent with WTO negotiations. It is particularly relevant in this regard for it has been based on diagrammatic analysis of welfare theory and has simplified the concepts of consumer and producer surpluses for a clear understanding of the resultant welfare implications in terms of gains and losses. In spite of the theoretical merits, the paper however, remains deficient in four major respects as follows:

Firstly, the paper provides only a partial coverage to WTO agreement on agriculture. For example, although it covers export subsidies, there is no mention of general subsidies on agricultural inputs or aggregate measures of support for agricultural production. There is hardly any discussion on tarrification, quantitative or other trade restrictions and removal of quota. As sanitary and phyto-sanitary measures, multifiber agreement, product standardisation, anti-dumping laws and trade related intellectual property rights also have relevance though an indirect one, there was definite need to give some importance to each of these topics in the paper.

Secondly, the paper lacks uniformity of analysis. Although the paper was mainly concerned with Pakistan, as the title shows, the analysis is quite general in the beginning but becomes increasingly specific to United States of America, Europe and Pakistan towards the end.

Thirdly, the paper does not seem to be consistent with its title. For example, it makes no mention of poverty in the paper, other than in the title, and fails to develop an effective link between consumer and producer surpluses on the one hand and growth and poverty on the other. Apart from the trends in consumer and producer surpluses, poverty is also a function of prices and redistributive effect of growth. The available worldwide empirical evidence suggests that elimination of general and export subsidies in agriculture are most likely to lead to a fall in agricultural production and a rise in agricultural commodity prices. As a result, it means greater hardship for the less developed poor and food importing countries of the world. What is more important to note is the fact that the poorest of the poor within each of these countries are likely to face even greater starvation and misery. However, the situation might vary from country to country depending on the response to price hike in agricultural commodities. In the case of Pakistan, a favourable impact of WTO agreement on agricultural output may be expected, as Pakistan has a comparative advantage in the production of most agricultural commodities other than sugarcane, 
agricultural commodities are considerably under-priced and subsidies on key agricultural inputs have already been withdrawn. However, an increase in food prices may have adverse effect on urban poor especially in the short run. In the long run, the higher prices may induce higher output and the trend in poverty would then be shaped by the response of various classes of farm sector involved in the production process.

Finally, the paper contains lot of grammatical and other errors and it sometimes becomes awfully difficult to make sense out of the text. It, therefore, may not be irrelevant to request the authors to seek editorial advice from an expert in this field.

Pakistan Institute of Development Economics,

\section{Ghaffar Chaudhry}

Islamabad. 